Article

\title{
Sustainability Education in China: Lessons Learnt from the Teaching of Geography
}

\author{
Haoyi Huang and Eddie W. L. Cheng * \\ Department of Social Sciences, The Education University of Hong Kong, Tai Po, Hong Kong; \\ s1126279@s.eduhk.hk \\ * Correspondence: wlcheng@eduhk.hk
}

check for updates

Citation: Huang, H.; Cheng, E.W.L. Sustainability Education in China:

Lessons Learnt from the Teaching of Geography. Sustainability 2022, 14, 513. https://doi.org/10.3390/ su14010513

Academic Editors: Changhyun Roh and Jesus Martinez-Frias

Received: 29 November 2021 Accepted: 27 December 2021

Published: 4 January 2022

Publisher's Note: MDPI stays neutral with regard to jurisdictional claims in published maps and institutional affiliations.

Copyright: (C) 2022 by the authors. Licensee MDPI, Basel, Switzerland. This article is an open access article distributed under the terms and conditions of the Creative Commons Attribution (CC BY) license (https:// creativecommons.org/licenses/by/ $4.0 /)$.

\begin{abstract}
Since its emergence, the concept of sustainability has been incorporated in geography education across the globe. China is no exception. As one of the pioneer countries in advocating environmental protection, the Chinese government has called for a paradigm shift in pedagogies in order to encourage students to effectively learn the concept and develop their ability to think in new ways, especially engaging themselves with contemporary worldviews. However, many teachers may feel that they are incapable of teaching sustainability. Therefore, it is important to examine whether subject teachers have the ability to implement sustainability education. To fill this research gap, the present research focused on a case study of an in-service Chinese geography teacher teaching sustainability in a junior middle school in China. In order to deeply understand his teaching, this research adopted the form of interviews, supplemented by the analysis of relevant teaching documents. The results indicated that the two themes taught in the seventh and eighth grades, respectively, involved mainly environmental sustainability with some connection to economic sustainability, but fell short of socio-cultural sustainability. This study calls for more sustainability elements in geography curriculums, particularly with the inclusion of socio-cultural sustainability. In this article, research and practical implications have been given.
\end{abstract}

Keywords: sustainability; sustainability education (SE); education for sustainability (EfS); education for sustainable development (ESD); geography education; Chinese curriculum

\section{Introduction}

The term "sustainability" is known to be a solution to environmental and social problems [1]. Sustainability is defined as "meeting the needs of the present without compromising the ability of future generations to meet their own needs" [2]. It emphasizes "social, economic and environmental sustainability and the interaction of these three elements" [3] (p. 246). Another related term is sustainable development (SD), which refers to a development that achieves sustainability [4]. It is understood that SD involves a process that helps create a world of global social equality, where the natural system that supports human existence can be maintained [5]. As it is good for the planet, sustainability has been incorporated in education with the aim of raising students' awareness of their "responsibility for the environment, well-being and a sustainable future" and the importance of developing their "future-oriented thinking and the building of the future upon ecologically, economically, socially and culturally sustainable premises" ([6] (p. 39) cited from [7]). It is important for students to effectively learn the concept and develop their ability to think in new ways so as to better engage themselves with contemporary worldviews [8]. In light of this, sustainability education (SE), also known as education for sustainability (EfS) or education for SD (ESD), is recognized as an internal element of the fourth (i.e., quality education) of the seventeen United Nations' (UN) SD goals and has been incorporated into school curricula around the world [9]. China is no exception. As one of the pioneer countries in advocating environmental protection, the Chinese government has called for a paradigm shift in pedagogies that should be problem-solving-based and sustainability-centered [10]. 
According to Yli-Panula et al. [11] (p. 1), geography refers to "the study of human activities and their interrelationships and interactions with environments on local to global scales," and it should therefore offer a highly appropriate home for SE [3]. Since its emergence, the concept of sustainability has been incorporated in geography education across the globe. For example, in Australia, sustainability has been one of the three crosscurricular priorities in the school curriculum [12]. SD has also been a focal point in the Swedish geography curriculum [5]. In China, a sustainability-oriented and problem-based pedagogy of geography has been adopted for dealing with SD issues; however, this SDoriented curriculum is considered to be led by government consultancy and policy tasks, so it lacks theoretical and philosophical in essence [10]. It is understood that "teaching SD in geography depends not only on high-quality subject matter knowledge, but also on modern researched pedagogical content knowledge," which implies that "teachers' interpretations and transformations of subject matter knowledge in the context of facilitating student learning" become more important [11] (p. 2). In considering this, China's current teaching practice of sustainability in geography is worthy of scrutiny, especially as the most populous country in the world. In order to draw meaningful implications, it is also necessary to explore the views of Chinese teachers on SE, including what problems they face in teaching sustainability in geography and how they solve these problems.

This study focuses on geography teaching in junior (or lower) middle schools. As noted by Noble and McGrath [13], it is important to help young people become resilient, while they are growing to be an independent adult. The education system should be able to prepare students with a positive mindset so that they can think logically and are able to distinguish right from wrong. In fact, it is vital to increase their understanding of sustainability during their mental development stage. Yet, many teachers may feel that they are incapable of teaching sustainability [14]. Therefore, it is important to examine whether subject teachers have the ability to implement SE [7]. To fill this research gap, the present research focuses on a case study of an in-service Chinese geography teacher teaching sustainability in a junior middle school in China. Documents, including study plans, subject contents and other teaching materials supplied by the teacher were analyzed and his reflections regarding his teaching were collected through an online interview. The lessons learnt help to explain the difficulties faced by Chinese teachers in SE and are expected to be helpful to guide not only local Chinese teachers but also teachers around the world in designing viable sustainability programs.

\section{SE in China's Junior Geography Curriculum}

\subsection{Geography Education in China}

China's revised edition of the new geography curriculum standards for compulsory education (hereinafter the new China's standards) formulated by the Chinese Ministry of Education (CMoE) in 2021 [15] replaced the 2011 edition. Yet, the new edition has no significant difference from the old one. According to the China's standards, modern society requires citizens to scientifically and fully understand the importance of the coordinated development of population, resources, environment and society, establishing the concept of SD and constantly explore and follow scientific and civilized production methods and lifestyles. This puts forward the reform of geography curriculum that should help students form positive attitudes, values, behaviors and habits and build their ability to deal with population, resources, environment and development issues. In other words, geography curriculums should help cultivate active and responsible citizens for the environmental protection and SD of the country and the world. The nature of a geography curriculum reflects both natural and social principles and has five major characteristics: regional, comprehensive, ideological, life and practical (see Table 1 for details). Teachers should design a curriculum for students based on the following three basic considerations: (1) learning geography that is useful for life, (2) learning geography useful for lifelong development and (3) constructing an open geography curriculum (see Table 2 for full description). 
Table 1. The five major characteristics of a geography curriculum.

Characteristic
Regional
$\begin{gathered}\text { Geography curriculums are mainly based on regional geography, } \\ \text { showing the natural and humanistic characteristics of each region and } \\ \text { clarifying the geographical overview, development differences and } \\ \text { interregional connections of different regions. }\end{gathered}$
Comprehensive $\quad \begin{gathered}\text { Geographical environment is the interconnection of various natural and } \\ \text { human elements on the earth's surface, where such connections and } \\ \text { interactions form a complex system. Geography curriculums at the } \\ \text { compulsory education stage reveal the complex relationship between the } \\ \text { elements of the natural environment and between the natural } \\ \text { environment and human activities, reflecting the comprehensiveness of } \\ \text { the geographical environment from different angles. }\end{gathered}$
$\begin{gathered}\text { Geography curriculums highlight the population, resources, } \\ \text { environment and development issues facing today's society, clarify } \\ \text { scientific concepts of population, resources, environment and SD and are } \\ \text { rich in the ideas of loving hometown, loving the motherland, paying } \\ \text { attention to the world and SD. }\end{gathered}$
$\begin{gathered}\text { The content of geography curriculums is closely related to the reality of } \\ \text { life and highlights the geographical phenomena and possible }\end{gathered}$
geographical problems encountered by students in their lives, which
helps to improve the quality of life and survivability of students.

Table 2. Three basic considerations when designing a geography curriculum.

\begin{tabular}{|c|c|}
\hline & Description \\
\hline $\begin{array}{l}\text { Learning geography that is } \\
\text { useful for life }\end{array}$ & $\begin{array}{c}\text { Geography curriculums should choose basic knowledge of earth } \\
\text { and map, world geography, Chinese geography and rural } \\
\text { geography, which are closely related to life, to guide students to } \\
\text { discover geography problems in life, understand the geographical } \\
\text { background that they form, enhance students' taste in life and } \\
\text { enhance students' survival ability. }\end{array}$ \\
\hline $\begin{array}{l}\text { Learning geography useful } \\
\text { for lifelong development }\end{array}$ & $\begin{array}{l}\text { Geography curriculums should guide students to think of } \\
\text { problems from the perspective of geography, pay attention to } \\
\text { nature and society, so that students gradually form the concept of } \\
\text { man-land coordination and sustainable development and lay the } \\
\text { foundation for cultivating citizens with geographical literacy. }\end{array}$ \\
\hline $\begin{array}{l}\text { Constructing an open } \\
\text { geography curriculum }\end{array}$ & $\begin{array}{l}\text { Focusing on the cultivation of students' innovative consciousness } \\
\text { and practical ability, geography curriculums should attach } \\
\text { importance to the development and utilization of curriculum } \\
\text { resources inside and outside the school, broaden the learning } \\
\text { space, pay attention to diverse geography learning methods and } \\
\text { encourage students to learn independently, cooperate and } \\
\text { exchange and actively explore. }\end{array}$ \\
\hline
\end{tabular}

Source: CMoE [15] (in Chinese, semantic translation with minor modification).

Similar to overseas counterparts (e.g., [16]), the core concepts in geography education in China involve space, place, landscape and sustainability. Each geography curriculum in compulsory education is further divided into four parts: earth and maps, world geography, Chinese geography and rural geography [15]. Among them, "Earth and Map" is the basis for learning regional geography. In principle, a curriculum at the junior level should not involve deeper issues of geography. Geographical elements are listed separately and com- 
bined with regional geography. For example, the natural part of world geography only lists climatic elements, while other physical geography elements are included in the relevant regional content. In the regional part of world geography and Chinese geography, except for the regions specified in this standard, other regions are selected by the textbook writers and teachers. This standard only lists the basic geographical elements of the region and the basic knowledge and basic skills that must be mastered to learn regional geography, as well as the number of required regions. Rural geography can be used not only as a part of the whole curriculum, but also as the core of comprehensive learning. Students can use their geographical knowledge and skills to conduct exploratory practical activities centered on environmental and development issues through collecting information around them. The general goal of the compulsory education phase of geography learning is to master basic geography knowledge, acquire basic geography skills and methods, understand environmental and development issues, enhance patriotic affection and form global awareness and the concept of SD. Table 3 lists the three important aspects, which form an organic whole in the implementation process.

Table 3. Important aspects for implementing a geography curriculum.

\section{Description}

1. Master the basic knowledge of the earth and maps and be able to preliminarily explain the role of topography, climate and other natural geographical elements in the formation of the geographical environment and the impact on human activities; preliminary understanding of the regional differences in population, economic and cultural development.

2. Understand the general geography of hometown, China and the world and understand the relationship between hometown

Knowledge and skills and the motherland, China and the world.

3. Understand the major issues facing human beings such as population, resources, environment and development and have a preliminary understanding of the relationship between the environment and human activities.

4. Master the basic skills of obtaining geographical information and expressing geographical information in the form of words, images, etc., grasp the skills of simple geographical observation, geographical experiment and geographical survey.

1. Perceive the geographical things and phenomena around a person through various ways and accumulate rich geographical representations; initially learn to form geographical concepts, summarize geographical features and understand geographical laws through the thought processes of comparison, analysis and induction based on the collected geographical information.

2. Use the acquired basic concepts and basic principles of

Process and method geography to analyze geographical things and phenomena and make judgments.

3. Have a sense of innovation and practical ability, be good at discovering geographical problems, collecting relevant information, using relevant knowledge and methods and putting forward ideas for solving problems.

4. Use appropriate methods and methods to express and communicate the experience, ideas and results of learning geography. 
Table 3. Cont.

\begin{tabular}{|c|c|}
\hline & Description \\
\hline $\begin{array}{c}\text { Emotions, attitudes and } \\
\text { values }\end{array}$ & $\begin{array}{l}\text { 1. Enhance the curiosity of geographical things and phenomena; } \\
\text { increase the interest in learning geography and the aesthetic taste } \\
\text { of the geographical environment. } \\
\text { 2. Caring of the environment and development of the hometown, } \\
\text { caring of the basic geographical conditions of our country and } \\
\text { enhancing the emotion of loving hometown and the motherland. } \\
\text { 3. Respect the culture and traditions of different countries in the } \\
\text { world, enhance national self-esteem, self-confidence and pride, } \\
\text { understand the meaning of international cooperation and initially } \\
\text { form a global awareness. } \\
\text { 4. Initially form the awareness of respecting nature, living in } \\
\text { harmony with nature, adapting measures to local conditions and } \\
\text { the concept of SD, enhancing the awareness of preventing natural } \\
\text { disasters, protecting the environment and resources and } \\
\text { complying with relevant laws and regulations and developing the } \\
\text { habit of caring for and caring for the geographical environment. }\end{array}$ \\
\hline
\end{tabular}

Source: CMoE [15] (in Chinese, semantic translation with minor modification).

\subsection{Geography Taught in Junior Middle Schools}

Cai [17] provided some insightful views of both seventh and eighth grades on learning geography. She commented that compared with other core subjects like mathematics, geography is a brand new subject for seventh graders. Students learn the time and space of geographical science. The abstract knowledge of celestial bodies, coupled with the complicated earth movement and the resulting geographical significance, makes junior students feel extremely confused. This difficulty may increase when Chinese students learn the urban spatial structures that are mainly explained by the post-modernist discussions that focus on apparent forms rather than substantive contents [10]. Although capable students can adapt well to the situation, other students may find it difficult to learn the subject. Therefore, how to help seventh graders adapt to geography learning is particularly important. In the eighth grade, geography plays the role of letting students know the motherland affectionately, leading them to "travel" the mountains and rivers of the motherland, admire the rich traditions of various places and experience the unique charm of ethnic minorities. Therefore, in the classroom, geography teachers should let students experience the richness and happiness of geography classes while learning geography knowledge.

According to the new standards, compulsory education geography aims to help students acquire geographical knowledge, skills and methods, understand the geographical environment, guide students to actively participate in geography practice activities and encourage students to identify and solve geographical problems. Cai [17] attempted to understand the difficulty level of studying geography at junior middle schools. Through the analysis of the learning objectives in terms of knowledge, skills, processes, methods, attitudes and values in the junior geography curriculum standards, she identified the main words that described the learning objectives. Table 4 exhibits the number of occurrences of these words. She found that the level of the overall curriculum objectives was quite shallow. According to the Bloom's Taxonomy [18], the curriculum was mainly set at the lower-order level. Teachers engaged in junior geography teaching should carefully grasp the requirements of the curriculum standards in order to properly guide their teaching.

Moreover, Cai [17] also investigated into the situation of junior students' learning of geography. She randomly selected classes of seventh and eighth grades from the school in which she was teaching and established a sample of 72 students at the seventh grade and 60 students at the eighth grade. Their responses to a set of questions, including the level of difficulty and usefulness, were recorded. It can be seen from Table 5 that more than $70 \%$ of the seventh grade students thought that the geography subject was very difficult or difficult to learn; only a few respondents said that the geography subject was easy to learn. More 
than $90 \%$ of junior school students thought that the geography subject was useful, and it was positively related to the proportion of people who liked the geography subject. It shows that junior school students were full of interest in geography learning. In terms of teaching methods, students were more inclined to the use of learning activities. It is interesting to find that the eighth grade students were engaged in more self-learning, indicating that students had adapted to the study of geography and started feeling that the knowledge was not difficult to understand. In terms of teaching aids, it is more inclined to integrate modern computer technology as well as the use of geography teaching equipment. The term "digital wisdom" raised by Prensky [19] has been used to define a digitally intelligent person who "uses digital technologies and available techniques to enhance his or her mind, as well as other human capabilities" [20] (p. 169). Therefore, more teaching equipment and computer technology should be introduced in geography teaching of junior middle schools. In terms of classroom practices, the humorous style of teaching was preferable by most of the students.

Table 4. The number of occurrences of the words that describe the learning objectives.

\begin{tabular}{ccc}
\hline Knowledge and Skills & Process and Methods & Attitudes and Values \\
\hline Master (4) & Perceive (1); utilize (2) & Care (1) \\
Preliminary describe (1) & Preliminary master (1) & Preliminary form (1) \\
Preliminary understand (2) & Collect (1); propose (1) & Build caring (1) \\
Understand (3) & Express (1); share (1) & Strengthen (4) \\
\hline
\end{tabular}

Note: Source from Cai [17] (in Chinese, semantic translation with minor modification); numbers in parentheses are the frequency of occurrence of the words that describe the learning objectives.

Table 5. Geography teaching and learning perceived by junior school students.

\begin{tabular}{|c|c|c|c|c|c|c|}
\hline & Seventh & Eighth & Seventh & Eighth & Seventh & Eighth \\
\hline $\begin{array}{l}\text { Difficulty } \\
\text { level }\end{array}$ & $\begin{array}{l}\text { Very difficult } \\
\quad(5.6 \%)\end{array}$ & $\begin{array}{l}\text { Very difficult } \\
\quad(8.2 \%)\end{array}$ & $\begin{array}{l}\text { Quite difficult } \\
\qquad(69.4 \%)\end{array}$ & $\begin{array}{l}\text { Quite difficult } \\
\qquad(16.4 \%)\end{array}$ & $\begin{array}{c}\text { Easy } \\
(25.0 \%)\end{array}$ & $\begin{array}{c}\text { Easy } \\
(75.4 \%)\end{array}$ \\
\hline Usefulness & $\begin{array}{c}\text { Very useful } \\
(34.7 \%)\end{array}$ & $\begin{array}{l}\text { Very useful } \\
(16.4 \%)\end{array}$ & Useful (58.3\%) & Useful (77.0\%) & Useless $(7.0 \%)$ & Useless $(6.6 \%)$ \\
\hline Likeness & Very like (36.1\%) & Very like (45.9\%) & $\begin{array}{l}\text { Quite like } \\
(56.9 \%)\end{array}$ & $\begin{array}{c}\text { Quite like } \\
(54.1 \%)\end{array}$ & Dislike (7.0\%) & $\begin{array}{c}\text { Dislike } \\
(0 \%)\end{array}$ \\
\hline $\begin{array}{l}\text { Teaching } \\
\text { method }\end{array}$ & $\begin{array}{c}\text { Teacher-led } \\
(12.5 \%)\end{array}$ & $\begin{array}{c}\text { Teacher-led } \\
(6.5 \%)\end{array}$ & $\begin{array}{l}\text { Interactive } \\
(84.7 \%)\end{array}$ & $\begin{array}{l}\text { Interactive } \\
(82.0 \%)\end{array}$ & Self-learning $(2.8 \%)$ & Self-learning $(11.5 \%)$ \\
\hline Teaching aids & $\begin{array}{l}\text { Printed materials } \\
\qquad(2.8 \%)\end{array}$ & $\begin{array}{c}\text { Printed materials } \\
(3.3 \%)\end{array}$ & $\begin{array}{l}\text { Multimedia } \\
(41.7 \%)\end{array}$ & $\begin{array}{l}\text { Multimedia } \\
(59.0 \%)\end{array}$ & $\begin{array}{l}\text { Teaching equipment } \\
\qquad(55.5 \%)\end{array}$ & $\begin{array}{l}\text { Teaching equipment } \\
\qquad(37.7 \%)\end{array}$ \\
\hline $\begin{array}{l}\text { Teaching } \\
\text { style }\end{array}$ & $\begin{array}{c}\text { Humorous } \\
(83.3 \%)\end{array}$ & $\begin{array}{c}\text { Humorous } \\
(88.5 \%)\end{array}$ & Serious $(4.2 \%)$ & Serious $(3.3 \%)$ & Random (12.5\%) & Random $(8.2 \%)$ \\
\hline
\end{tabular}

Note: Source from Cai [17] (in Chinese, semantic translation with minor modification); numbers in parentheses are the percentages of students who responded to a set of questions, including the level of difficulty and usefulness.

\subsection{SD in Junior Geography Curriculum}

As stated in the new China's standards, the nature of the geography curriculum at the compulsory education stage is to understand the geographical environment and form geographical skills and SD concepts [15]. As noted by Çifçi and Koybaşi [21], "in the context of education, gaining geographical consciousness can be employed as a key to sustainability" (p. 53). Thus, SE has already become a part of the standard geography curriculum. Teaching geography for SD is perceived as critical geography education, which challenges the traditional way of teaching the subject [20]. According to Yli-Panula et al. [11], SE in geography should involve SD learning that can generate holistic experiences around philosophical, theoretical and practical sustainability issues.

Zhang et al. [22] provided examples showing how the concept of SD can be infiltrated in teaching. They mentioned that after learning the content of themes of "continents and oceans" and "transformation of land and sea", geography teachers can organize students to conduct research and discussion on the theme of "various seas and connecting straits" and learn about crustal movement and the formation process of the continents and oceans, as well as what impacts these will have on human beings. For example, the hazards caused 
by the violent movement of the earth's crust, such as the Ya'an earthquake, will not only cause a lot of damages, but will also bring benefits to mankind, such as new energy sources. Further expanding the classroom teaching to let students learn how to avoid danger in an earthquake, protect life and property as much as possible and use geographical knowledge to serve life better may be considered.

Moreover, teachers should let students jump out of the normal textbook content and walk into the life around them. Zhang et al. [22] used "changeable weather" as an example to illustrate that practical activities can be carried out on relevant festivals, such as World Environmental Day on the fifth of June, requiring students to collect relevant news reports regarding the occurrence of haze in Beijing, Shanghai and other cities and arranging roleplaying dramas in the class to understand the impact of environmental pollution on daily life. It is crucial to guide students to actively find solutions to problems. Under the guidance of teachers, students may launch special lectures on environmental protection through cultural performance activities, campus broadcasts, green campuses and other forms of publicity in the school, calling for more students to participate in environmental protection, so that they can understand the environment and the importance of protecting it.

Yet, SE is argued to be a complex and controversial approach, and therefore it is a challenge for subject teachers [7]. SE serves as a multi-faceted form of education that will train students in different ways for addressing different sustainability issues [5]. Clearly, there are different approaches that can be used to teach sustainability [23]. For Roberts [24], "it is easier to determine what geography teachers teach than to influence how they deliver the content" (p. 237). Therefore, in order to teach successfully, teachers should help students set up effective learning activities and should be able to evaluate the use of these teaching and learning strategies to bring about the desired aspects of learning in geography [25]. The aim of this case study is to explore the difficulties in teaching sustainability in China's junior school, as well as how competent the teacher feels in teaching with SE. Through the lens of a Chinese teacher, this study helps to generate insights for those who would like to teach sustainability, whether in China or beyond. The research questions for this study are:

- What SE had been incorporated in the geography curriculum? To what extent did such teaching match the curriculum standards of the country as well as the world?

- How did the subject teacher perceive his competence in teaching sustainability? What difficulties did he face? How could he handle such difficulties?

\section{Research Method}

\subsection{Data Collection}

This research adopted a single-case study method to explore the lessons learnt from a Chinese teacher's teaching through the design and delivery of geography lessons with SE in a junior secondary school in China. The case study method is mainly used to examine and understand the current situation and practical phenomena in a real environment and uses multiple methods to collect data from one or more sources, which can be a person, a group, or an organization. Yin [26] argued that the case study method is suitable for addressing the research question that primarily seeks to know the "how" and "why" of social phenomena or to deeply observe a single social phenomenon. There is no shortage of case studies with a single teacher as the subject. For example, Sugimoto [27] explored the dilemmas faced by a teacher when working with English language learners in a lowincidence school in the US, while Rissanen, Kuusisto, Tuominen and Tirri [28] drew the experience from a Finnish teacher on how she pursued core features of growth mindset pedagogy. Kooloos, Oolbekkink-Marchand, Kaenders and Heckman [29], on the other hand, looked into the problems of teaching mathematics by a Dutch secondary-school teacher. Although they all focused on a single teacher in their studies, such a single-case study is still valuable due to the fact that "single cases can enable the creation of more complicated theories than multiple cases, because single-case researchers can fit their theory exactly to the many details of a particular case" while "multiple-case researchers retain only the relationships that are replicated across most or all of the cases" [30] (p. 30). That 
is, a single subject should be used when one wants to contribute to theory development "if the particulars of the case are seen as opportunities to make further adjustments in an already crystallized understanding of reality" [31] (p. 362). In fact, the reason for choosing this teacher as the subject of this study was that he represented a younger teacher with less experience in teaching geography. The analysis of his teaching together with his difficulties in teaching sustainability would help draw new insights, where "the main goal is not to seek the general laws that operate in the particular case, but to allow a better view, a better explanation" [31] (p. 362), which is the "lessons learnt" mentioned in this study. Ethical clearance was obtained for this study.

The aim led to the examination of the teaching documents obtained from the teacher and his reflections collected through an in-depth interview with him. Specifically, the case referred to the teaching of sustainability in geography as the theme story, and the repercussions aroused by it has its own unique phenomenon, which is worth exploring. The in-depth interview was used to deeply understand the teacher's teaching; that is, it is interesting to know whether the teacher has faced any difficulties in teaching sustainability in the geography curriculum and how he has overcome the difficulties. The teacher was contacted three times to obtain the required teaching materials, including study plans, part of subject contents and other teaching aids, for two themes; that is, one theme was taught in one lesson in the seventh grade, while the other in the eighth grade. He was then interviewed one time with approximately thirty minutes. Major questions include how the teacher taught the two themes, what sustainability elements were covered in the two lessons, what difficulties he encountered in teaching sustainability and how students performed in and reacted to the lessons. He spent approximately ten minutes for describing each lesson, while spending approximately ten minutes for discussing the difficulties in teaching sustainability. After this main round of interviews, he was contacted three times, each for approximately five minutes, to clarify questions regarding his teaching in order to compile his whole teaching experience. His reflections and relevant teaching materials formed the basis for analysis.

\subsection{Data Analysis}

This research followed the concept of triangulation suggested by Denzin et al. [32], using different angles to confirm the existence of a certain fact and concept, also known as cross-examination. The triangulation of data is to point out the appearance of the research phenomenon through the cross-comparison of the facts, reducing the bias caused by unilateral data and confirming the connotation of facts through repeatedly discussing and comparing by the researchers, who analyzed the teacher's reflections and the related documents with mutual confirmation and testing, in order to strive for the completeness and correctness of the data content. Once there was a consensus by the researchers, the results of the analysis were confirmed.

This case study mainly summarized and analyzed the content of teaching activities and the reflection from the teacher. In order to deeply understand the teaching, this research followed the interpretative methodology suggested by Granados Sánchez [20]. The main findings were generated through the curricular analysis in terms of the following three sets of criteria.

First, this study followed the UN's criteria for finding sustainability in existing curricular. These criteria were developed from the concept of ESD implemented by the UN (hereinafter the UN's ESD), which aimed to "help build commitment and skills across the world's education systems so that children and youth could develop an enhanced understanding of what it means to work for a sustainable future, a sense of responsibility for future generations and a spirit of optimism and hope for a sustainable future" [20] (p. 161). Although each geography curriculum should be made with the objectives and contents related to regional and national needs [33], the reorientation of the geography curriculum to ESD has a global perspective, which offers the general directions for learning geography. Therefore, this research assessed the extent to which the teaching content matched the 
criteria. To analyze the curriculum, "one needs to look for concepts that are related to the three spheres of sustainability-environment, society and economy-as well as the sustainability's themes that are important to the local community or country" [34] (p. 43). The former highlighted the need for matching the general standards set by the UN, while the latter focused on the standards set by China.

Second, the analysis involves the identification of the concepts that form the basis for understanding sustainability and that are related to sustainability. For example, the knowledge of what natural resources are is fundamental to learning of conservation or the use of natural resources pertaining to sustainability [34]. Without the basic concept, it would be difficult to understand the importance of sustainability. These criteria somewhat coincide with the traditions in Sweden, where there are three choices for geography teaching with SD: (1) the fact-oriented tradition, in which the basic geographical knowledge building on scientific facts are taught, (2) the normative tradition, in which students learn environmentally-friendly values and behaviors and (3) the pluralistic tradition, in which students are trained in creative and critical thinking toward sustainability issues [5].

Third, since the goal of promoting SD and teaching of SD in geography is to let students understand the interdependency between humans and nature [11], this case study also considered the Venn diagram from Raath and Hay [25]. Adapting from De Sousa [35], the Venn diagram illustrates the relationships among the three spheres of sustainability (Figure 1) to highlight the concept of systems thinking that is crucial for students to understand the complexity and dynamics of environmental, social and economic systems [36,37]. As shown in Figure 1, the interconnections among the three spheres indicate the sustainable literacy that reflects the complexity and dynamics of sustainability. Thus, the aim of SE is to develop students with new knowledge and new ways of thinking for sustaining social, natural and economic prosperity. In this study, we attempted to explore whether the discussion of such interconnections was covered in the curriculum to underline the impacts of the interrelated systems.

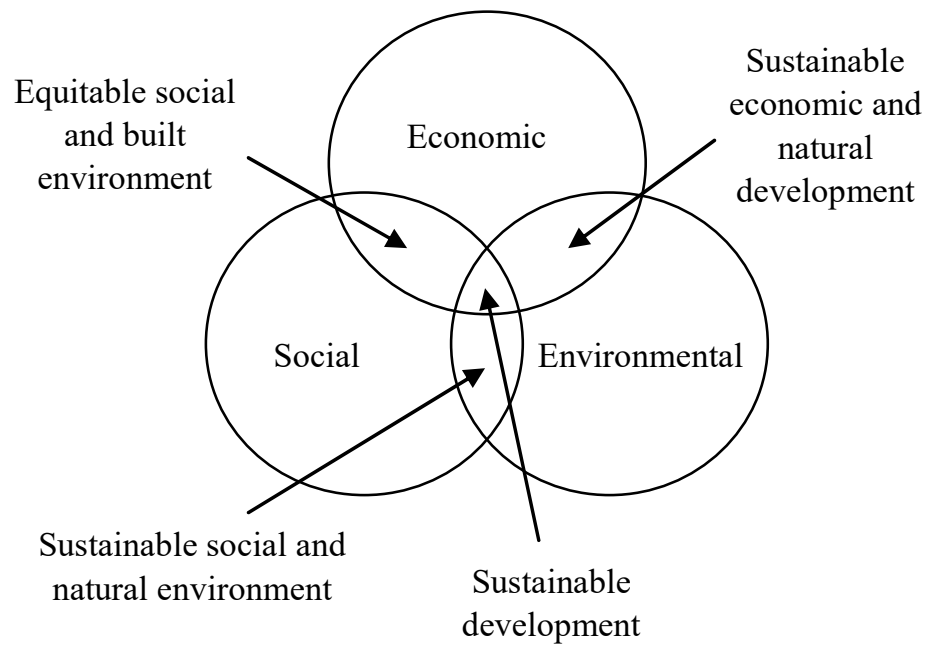

Figure 1. The Venn diagram of the relationships among the three spheres of sustainability. Note: Adapted from Raath and Hay [25].

\section{Results}

\subsection{The Theme of the Loess Plateau}

The teacher had taught the subject of geography for students in the seventh and eighth grades for five years. Each lesson lasted for 45 minutes. In the seventh grade, the teacher incorporated the concept of sustainability in the theme of the Loess Plateau (also known as Huangtu Gaoyuan), which is the world's largest loess accumulation area. There were four learning objectives as follows: 
(1) Use the topographic map to point out the geographical location and scope of the Loess Plateau;

(2) Understand the characteristics of the natural environment of the Loess Plateau and its influence on folk customs;

(3) Identify the reasons for the formation of the Loess Plateau from graphic data;

(4) Analyze the causes and consequences of soil erosion in the Loess Plateau through experiments, materials and group research and summarize the control measures and experience of soil erosion.

These four learning objectives did match the new China's standards. For example, the new standards have urged teachers to teach the basic regional geographical elements of rural areas and discuss environmental and development issues with the concept of SD. Such environmental awareness and consciousness are the common goals for learning both geography and sustainability [21]. These learning objectives formed the basis for setting the teaching modules for this theme. In fact, these modules must help promote knowledge, skills and attitudes for better understanding the existence of one's own culture and the relationships with other cultures and the universe [11]. Figure 2 shows a brief summary of the five modules for learning Loess Plateau in Chinese. In the figure, the teacher focused on five modules for studying this famous loess accumulation area: (1) the cradle of Chinese civilization, which includes the introduction of the location and scope of the Loess Plateau, the reason why it became the birthplace of the Chinese civilization and the characteristics of the natural environment of the Loess Plateau; (2) colorful local customs, such as cave dwellings and Xintianyou (talking face-to-face using a high-pitched voice); (3) the theories that explain the formation of the Loess Plateau, including Fengcheng Theory and Landform of the Loess Plateau; (4) soil erosion in the Loess Plateau, including causes, harms and governance measures for soil and water conservation; (5) SD for developing a better future.
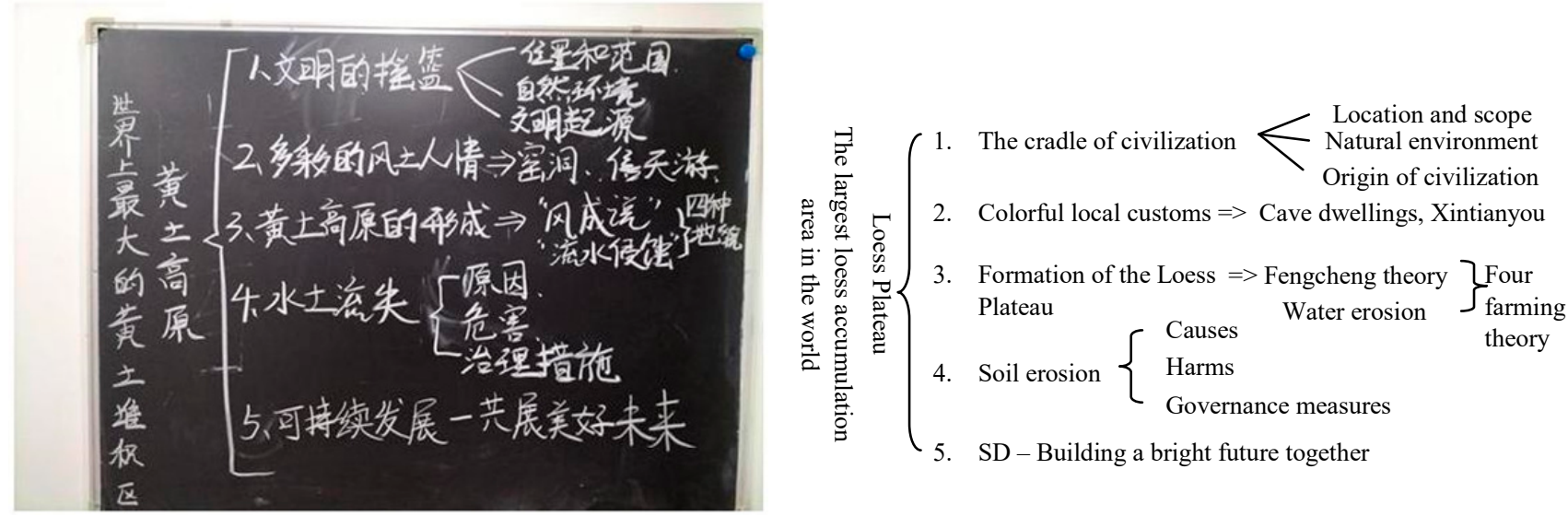

Figure 2. A brief summary of the five modules for learning Loess Plateau (originally in Chinese only). Source: Supplied by the teacher.

The content of the first four modules was based on the prescribed textbook, while the fifth module was made by the teacher, who mainly built this last module on the fourth one. For the fourth module, the teacher summarized the natural and human-made causes of soil erosion in the Loess Plateau and played videos related to soil erosion to discuss the harm caused by soil erosion. The teacher further mentioned that soil erosion has made the land more and more barren; soil erosion has worsened the ecological environment and induced natural disasters; soil erosion has raised the river bed and caused floods. As shown in Figure 3, the surface of the Loess Plateau is fragmented and dilapidated, which is very different from what we usually call the endlessly flat and wide plateau scene. The main reason for this situation is the long-term soil erosion. The teacher then concluded this module by demonstrating the causes of soil erosion and dividing students into several groups to discuss on how to solve soil erosion caused by vegetation, precipitation, terrain 
slope and human factors. Group discussion is one of the effective methods for teaching and learning, although it is not as popular as interactive learning, group projects, inquiry-based learning and experiential learning [11]. After that, the teacher taught the fifth module through summarizing the fruitful results from the measures taken by the government to protect the area.

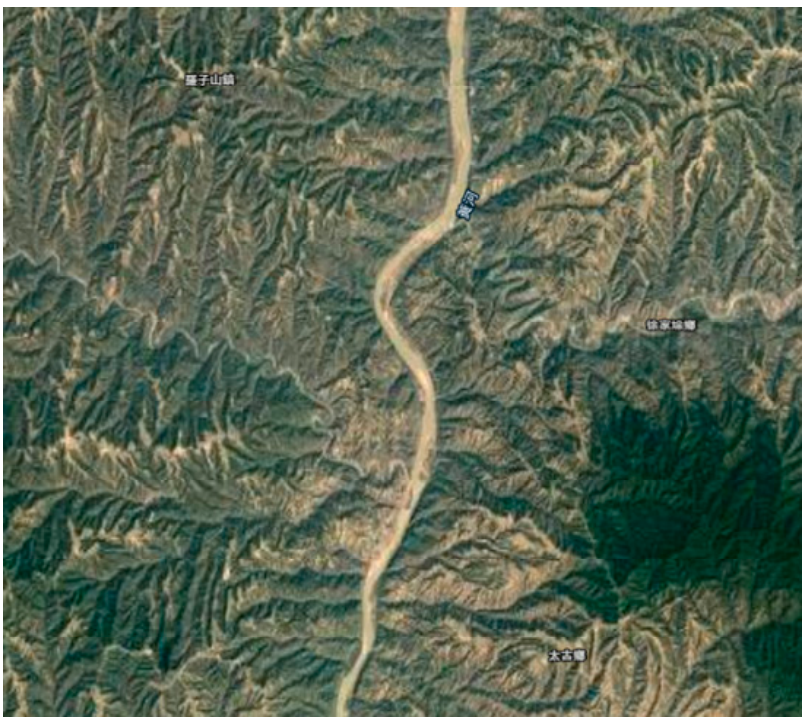

\title{
根治严重水土流失
}

从图片可以看出, 黄土高原的地表千沟 万壑、支离破碎。这与我們通常所说的 一望无际、平坦宽阔的高原景象大不相 同。造成这种状况的主要原因, 就是这 里长期的水土流失。

\section{Solving soil erosion problems}

\author{
As shown in the figure, the surface of \\ the Loess Plateau is fragmented and \\ dilapidated, which is very different \\ from what we usually call the endlessly \\ flat and wide plateau scene. The main \\ reason for this situation is the long-term \\ soil erosion. [semantic translation]
}

Figure 3. Solving soil erosion problems in the Loess Plateau affecting the Yellow River (originally in Chinese only). Source: Supplied by the teacher.

For teaching SD, the teacher compared the charts of the Loess Plateau before and after the treatment. He told the students that since the founding of the People's Republic of China (PRC), the party and the government have attached great importance to the ecological management of the Loess Plateau and have achieved world-renowned achievements. Through some graphic data, the teacher showed some of the governance results of the Loess Plateau; for example, the vegetation coverage of the entire Loess Plateau has increased from $7.1 \%$ in the early stage of the founding of PRC to the current $65 \%$, while the sediment content of the Yellow River has also dropped from 1 billion tons to 200 million tons. This results in the substantial improvement in the living standard of local farmers. It is clear that the curriculum designed by the teacher followed the new China's standards as well as the UN's ESD. Specifically, the teacher started from the particularity of the Loess Plateau and guided students to think actively and explore independently. Through some relevant activities, such as playing videos and group discussion, he aroused students' further thinking of curing and avoiding soil erosion from the perspective of sustainability, thereby sublimating the theme of this lesson. Such teaching and learning methods fostered cognitive, affective and psychomotor learning through goal-oriented activities and information exchange between the teacher and students $[11,38]$.

As seen from the five modules of the theme, the fifth module (i.e., SD for the future) was related to the fourth one (i.e., dealing with soil erosion). The teacher mainly discussed on how the government successfully dealt with soil erosion, which was seen by him as the SD for developing a better future in terms of environmental and economic considerations. However, he did not discuss how the cradle of Chinese civilization and the local social and cultural aspects could be inherited in the future. Although the first and second modules of the curriculum covered the environmental and societal aspects of the Loess Plateau, as the basic concepts required under the UN's ESD, the fifth module of sustainability did not link to these two modules. The content of SD taught by the teacher did not fully reflect what could be sustained in the area, implying that he might lack the competency in covering all aspects of sustainability in the theme. Although the details of how the area can be sustained 
may be too difficult to understand by the students of this age group, raising their interest, concern and care of the area, in terms of its nature, appearance and social and cultural characteristics, is essential, which complies with the new curriculum standards regarding sustainability as a core value that should be developed by students.

\subsection{The Theme of the Yangtze River}

In the eighth grade, students had to learn the development and governance of the Yangtze River (also known as Changjiang). This lesson aimed to use examples to sublimate and consolidate the knowledge of the river. Before learning the development of the Yangtze River, students mastered the former Chinese topography and the general conditions of the terrain and climate of the river, which formed the foundation for studying SD. For this theme, there were five learning objectives as follows:

(1) Understand the general situation of the Yangtze River;

(2) Know the areas where the Yangtze River flows, including administrative areas, topographical areas, etc.;

(3) Know the division of the upper, middle and lower reaches of the Yangtze River and understand the main characteristics of each river section;

(4) Understand the role of the Yangtze River as the "Hydropower Treasure" and "Golden Waterway" and its huge role in shipping;

(5) Understand the development of the Yangtze River and identify measures to control the Yangtze River.

SD elements were included in the fifth learning objective, while other learning objectives covered the basic knowledge of the river. This arrangement has met the UN's ESD and the new China's standards that the environmental and economic issues with sustainability should be built on the basic concepts. Additionally, there were four modules planned to achieve these five learning objectives. In the first module, students learnt the water system map of the Yangtze River basin, including the source and mouth of the river, the upper, middle and lower reaches, the main tributaries and lakes and the locations of the provinces that it passed through. This module was the background knowledge of the river. In the second module, students were divided into two groups to explain the origin of the two common names of the river: "hydropower treasure house" and "golden waterway". This module highlighted the economic benefit of the river. The third module was the problems found in the river, which included: (1) soil erosion in the upstream, (2) the flood disaster in the "Jiuqu ileum" part of Jingjiang and (3) the flood caused by the rapid flow of the river in the Chuan River. Similar to the previous theme, the above modules were made according to the prescribed textbook, while the fourth module was created by the teacher and included the SD of the river.

When teaching SD of the Yangtze River Basin, the teacher would like students to understand the ecological problems and solutions of the river. Therefore, the teacher requested students to think of the problems faced by the river and how such problems could be solved so that the river could be sustained in the future. For example, the teacher mentioned that through the study of the "Hydropower Treasures" and "Golden Waterways" of the Yangtze River, students understood the development capabilities contained in the river and its hydropower resources and water transport capabilities being in the forefront of the country. The teacher was also good to highlight the potential issues. He asked students some core questions. For example, were there any ecological problems during the development in the Yangtze River? Did human over-development conform to the idea of SD? What were the ecological problems in the upper, middle and lower reaches of the Yangtze River? What should people do to comply with the idea of SD? This has met both the new China's standards and the UN's SD that students should be able to realize that the economy and the environment are equally important and establish the SD idea. This coincides with the Venn diagram mentioned by Raath and Hay [25] that SE in geography should involve the study of the relationships between the environmental, socio-cultural and economic issues pertaining to sustainability. 
After the discussion among students, the teacher concluded that during the development of the Yangtze River, it would inevitably involve the destruction of the ecological environment. As shown in Figure 4, the ecological and environmental problems of the Yangtze River mainly included the following: (1) soil erosion in upstream, (2) middle reaches: sedimentation and flood disasters in the middle reaches and (3) downstream: water pollution in downstream. In view of such problems, the government has taken the following measures: (1) conserved soil and water and planted trees and grass in upstream, (2) returned fields to lakes and increased lake water demand in midstream (3) and controlled sewage discharge and reduced water pollution in downstream. Moreover, relevant laws and regulations were formulated to protect the river. In doing so, the ecological problems of the river were solved through the SD concept, resulting in obtaining economic as well as environmental benefits.

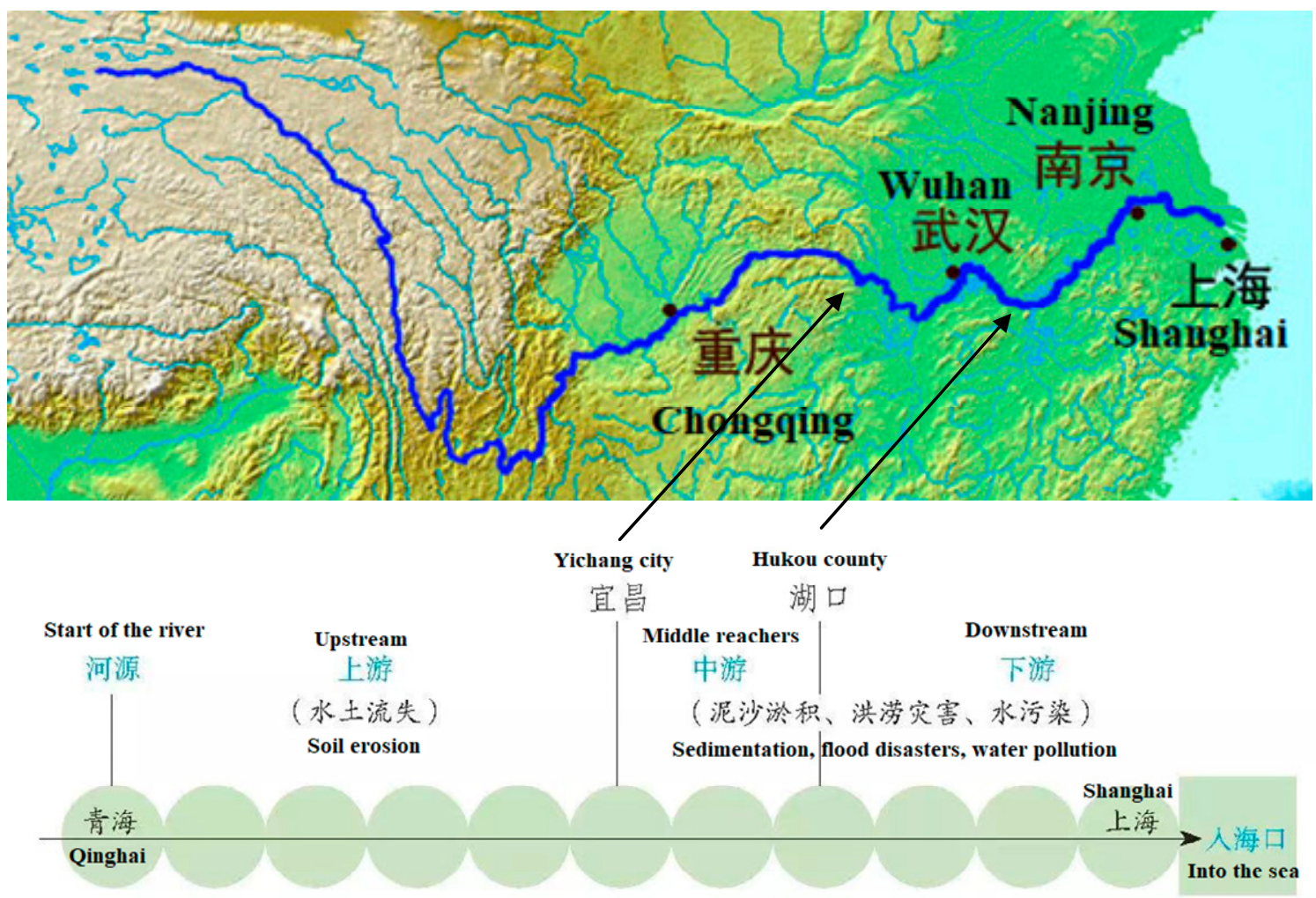

Figure 4. Ecological and environmental issues at different sections of the Yangtze River (originally in Chinese only). Source: Supplied by the teacher.

Similar to the seventh grade, the teacher did not discuss sustainability related to the social and cultural aspects along the river. Although students knew that the river passed through many provinces, how the socio-cultural heritage in these provinces can be sustained has not been discussed. As noted by Morgan [39], it is important to understand the social divisions and explore the complex social factors that create variations in social environments. Examples of the teaching of socio-cultural sustainability will be given in the next section.

\section{Discussion: The Lessons Learnt from the Case Study}

\subsection{Lack of the Emphasis on Sustainability}

The findings in the previous section reveal that the major components of the two themes were basic geographical knowledge, rather than sustainability knowledge, not to mention that sustainability was not included in other themes, such as World China Studies and Rain Forest Protection in Brazil and Southeast Asia, as admitted by the teacher. This is consistent with Witoszek [40], who found that Chinese students were not taught many 
sustainability elements. She used a sample of China's high school students (i.e., tenth to twelve grades) who were keen on university entrance examinations. This teachingto-the-test phenomenon can be found in many other Asian countries and regions, such as Singapore, Taiwan, Hong Kong, Japan and Korea. If SD is not an examination topic, students would not pay attention to it. A similar situation also occurred in junior middle schools (i.e., seventh to ninth grades). As the teacher admitted in the interview, SD was not the main concept to be assessed in the examination. Apparently, students were not interested in minor topics. If only simple questions were asked in the examination, students would not spend more time on learning the topic. In order to increase their interest, the teacher used video clips of natural disasters to tell students the importance of getting along with nature. Yet, video clips could not be used too much because there were many other geographical concepts to learn. Nevertheless, this teaching method could increase students' interest and enthusiasm in the classroom, thereby improving their understanding of the topic. The teacher further acknowledged that unless sustainability becomes the core examination topic, it would not attract too much attention from students and their parents who cared about their children's learning performance the most.

However, should the government instill and persuade students to adopt more sustainable thinking and actions? Obviously, the universal values promoted by organizations, such as the OECD and UNESCO, can lead to indoctrination and moralization [41], but "instructing students in how they should live their lives and the values to which they should conform is tantamount to denying them the possibility to shape their own future" [42] (p. 183) and forcing them to become citizens who do not have "worthwhile distinctions" [43] (p. 136). Although certain universal and national values are desirable in SE, students should be encouraged to put forward their own ideas. Against the anthropocentrism toward environmental ethics [44], Kowasch and Lippe [41] recommended the adoption of a more democratic classroom where students can express different views on sustainability and sustainable lifestyles; the ideal metaphor here is that the ideas of sustainability should not only be proposed by teachers, but also by their students. On the other hand, researchers may study what factors improve students' critical thinking. For example, the concept of "communication knowledge" may involve the discovery of knowledge generated by interaction with others [45], while the process of "self-confrontation" may form students" intentions to give meaning to their ideas, knowledge, values and interests [46] (p. 144).

In their empirical study of Austria and German schools, Kowasch and Lippe [41] reported that field trips were not common in SE. A didactic field trip refers to "an activity to be performed in groups outside the classroom in a geographical space that is a source of knowledge and which students access through an experience of motivation and personal development" [47] (p. 3). Bruckner and Kowasch [48] highlighted several challenges, such as time and resources, to such field experiences that are essential for students to develop their interests in SD. Due to the vast territory of China, it is very difficult to organize a field trip, especially when the location of the learning topic is far away from the school. In order to keep up with the national teaching content, the topic of study should be popular and worth knowing, such as Loess Plateau and Yangtze River that should be known to everyone. However, students who are more actively engaged with participatory experiences would increase their willingness to freely express their concerns and would enhance their competencies to act in accordance with their intentions. This refers to the pluralistic approach to SE, which aims to cultivate one's respect and openness to values and norms that differ from one's own [46], thereby promoting relational understanding of sustainable consumption and development [44]. Although organizing field trips in China may be too difficult, there are other activities that can help raise students' awareness of the moral issues in non-humans and post-materialist values. Researchers should explore such effective activities. For example, direct environmental experiences and gardening may help students reflect on their affective relationships with a particular issue [41]. Such direct experiences may involve a local problem, rather than a well-known national issue. This helps train students to focus on local sustainability practices, contributing to family 
subsistence and community life. School gardening allows students to develop their intrinsic values toward plants and animals [49]. These alternative educational approaches may help students and teachers use moral judgment, without hindering participation in ESD [48]. In fact, "practice opens space for interaction and exploration" [41] (p. 1077).

\subsection{Lack of the Teaching of Socio-Cultural Sustainability}

The findings indicate that the teacher mainly taught sustainability related to the environment and economy of the Loess Plateau and the Yangtze River. This moderately echoes the findings from Yli-Panula et al. [11], that the most frequently mentioned in the curriculums of geography with SD was environmental (ecological) sustainability, (e.g., climate change and groundwater), followed by social sustainability (e.g., gender equality, sustainable lifestyles and healthcare) and economic and cultural sustainability (e.g., traditional cultural knowledge and cultural knowledge of a place). Thus, teachers would prefer sustainability topics that are more related to environmental concepts than socio-cultural concepts. As noted by Cai [17], the subject of geography is new to both teachers and students of junior middle schools, so teachers may lack deep subject-matter knowledge regarding sustainability as well as the pedagogy for sustainability in geography [12]. In the new China's standards, the requirements in SD have not been explicitly stated. Moreover, in his self-reflection on the teaching of the lessons, the teacher admitted that the topic was difficult for lower-middle students and their motivation to learn was relatively low. This is consistent with Cai's findings [17] that the majority (more than 70\%) of the seventh graders in China thought that geography was very difficult or difficult to learn. More studies should then be focused on how to motivate students to learn. The theory of planned behavior has been widely used to explain students' intention to learn, such as participating in English programs in Chinese schools (e.g., [50]) and online collaboration in group projects [51]. It is worthwhile to study what factors contribute to students' sustainability learning.

In order to comply with the UN's goals for SD, socio-cultural sustainability contents of geography may consider such topics as human rights and gender equality [5]. For example, the teacher may discuss the interests and rights of peasant families in rural areas. According to Worden et al. [52], peasant families have taken a major role in the development of China. In the agricultural reforms that began in the late 1970s, rural families assumed more and more economic responsibilities, while the labor of family members was the main determinant of income. Yet, rural economic growth and commercialization increasingly rewarded managerial and technical skills and made unskilled agricultural labor less desirable. As long as this economic trend continues in the countryside in the late 1980s, peasant families preferred to have fewer but better educated children. This led to the huge mobilization of the skilled and knowledgeable labor force entering the cities, resulting in supporting the economic boom since the late 1990s [53]. In today's China, although rural families no longer owned land or passed it on to the next generation, they were allowed to build houses on their farms and had the right to pass on the houses to the next generation or sell them as commodities.

Regarding the topic of gender equality, the teacher may discuss the social realm of SD through the process of gender socialization [54]. Connell's [55] gender theory believes that children actively participate in the process of social construction. Fjellborg and Kramming [5] found that social sustainability favored female students more because they were more interested in topics related to the development of girls' and women's education, reproductive rights and social status in different parts of the world. However, this may reflect the lack of contents that can facilitate all students to learn. Perhaps, the emphasis on other social issues, especially those that affect their interests, may draw the attention of male students. For example, male students are more concerned over the potential to help the poor and the root causes of societal problems [56]. A broader scope of SD, illuminating all of the three dimensions of sustainability (i.e., environmental, social and economic), could lead to a larger selection of topics of interest by both male and female students [5]. As mentioned earlier, students should be encouraged to form their own ideas, which 
underscore the importance of communication, practical and social skills recommended by the UN, while a proper curriculum should "support and foster positive images of the future, awaken environmental sensitivity, facilitate system thinking and develop civic skills for sustainable lifestyles" [11] (p. 11). Geography teachers should encourage students to understand human-environment interactions through the analysis of nature-society relations [57]. Future research should consider using the Venn diagram shown in Raath and Hay [25] to depict the potential relationships between the three spheres of sustainability, especially the social-economic and social-environmental relationships, which are much less discussed in research and teaching practices.

\section{Conclusions}

All studies have limitations. A limitation of this study is the meaning of sustainability. This research follows the commonly known concept of sustainability, such as the one used by the UN. However, this may not be the most appropriate way to discuss sustainability, which is a new interdisciplinary field with many evolving definitions and approaches [3]. For example, the terms "weak" and "strong" sustainability are referred to as the planet's natural capital that can either be substituted with economic (financial) and/or human capital or fundamentally non-substitutable, respectively [58]. Although these terms were recommended to be adopted, they were rarely used in existing curricula [41]. Since they reflect concerns over natural rather than social capital, the current political agendas of most, if not all, countries do not take this into consideration. As the concept is still being debated [59], new developments of SE may drive teachers to develop new programs and new ways of teaching, which should form new research directions in the future. Moreover, this case study involved the analysis of the qualitative data of a single teacher. His experience may be dissimilar to that of other teachers working in a different environment. Its self-reported nature may further prevent it from achieving a high degree of objectivity. So, the findings of this study may not be generalized to other contexts and should be carefully interpreted. That being said, the lessons learnt are still useful suggestions for those who are or will be teaching geography. Comparing their own experiences with this case study may reveal similarities and differences that can help them generate their own insights. Further discussion on multiple case studies is beyond the scope of this research. For those who are interested in comparing cases, refer to Eisenhardt [60], Kessler and Bach [61] and Yin [31].

This study has presented evidence on how a teacher taught sustainability in geography to seventh and eighth grade students. The two research questions have been answered in detail in the two preceding sections. The answers and related challenges are briefly summarized below. First, in regard to what SE had been incorporated in the geography curriculum and the extent to which such teaching matched the curriculum standards of the country as well as the world, as we have seen, the two themes taught by the teacher involved mainly environmental sustainability with some connection to economic sustainability, but fell short of socio-cultural sustainability. Although China has long been regarded as the world's largest emitter of carbon dioxide, it has also become a global environmental forerunner [40]. With a highly centralized approach to the climate challenge, China may be able to derail "environmental Armageddon" [40]. According to the innovation theory, helping students develop a social innovation mindset makes them more aware of how to innovate and what might prevent them from innovating when they are faced with a sustainability issue [12]. As a country with the largest population in the world, attracting its people, including students, to the concept of sustainability in all relevant aspects is of particular importance. Second, from how the subject teacher perceived his competence in teaching sustainability, what difficulties he faced and how he could handle such difficulties, this study disclosed his preference for teaching environmental sustainability and difficulties in dealing with junior students who might lack motivation to learn sustainability due to the fact that it was not a major examination topic. Although he had made use of different activities, such as video clips, to increase students' interest in learning sustainability, he still lacked the skills to design a comprehensive curriculum for SE. As noted by Zhang et al. [22], 
education for SD in China has achieved certain results, but there are still unresolved problems, such as low penetration rate of SE in the geography classroom, lack of teacher training for SE, insufficient knowledge of SD of junior middle school students and poor practical skills of SD. In response to these difficulties, teachers should educate students with a mentality that sustainability is imperative. In addition, the government should formulate policies to strengthen teachers' pre-job and on-the-job training for sustainability, establish a platform conducive to the exchange of sustainability teaching, form a virtuous circle goal and promote the progress of SD.

Author Contributions: Conceptualization, H.H. and E.W.L.C.; methodology, H.H. and E.W.L.C.; software, H.H. and E.W.L.C.; validation, E.W.L.C.; formal analysis, H.H. and E.W.L.C.; investigation, H.H. and E.W.L.C.; resources, E.W.L.C.; data curation, H.H.; writing-original draft preparation, H.H. and E.W.L.C.; writing-review and editing, E.W.L.C.; visualization, H.H.; supervision, E.W.L.C.; project administration, H.H. and E.W.L.C.; funding acquisition, E.W.L.C. All authors have read and agreed to the published version of the manuscript.

Funding: This research was funded by The Education University of Hong Kong, grant number R6403.

Institutional Review Board Statement: The study was conducted according to the guidelines of the Declaration of Helsinki, and approved by the Institutional Review Board (or Ethics Committee) of The Education University of Hong Kong (with approval code: 2017-2018-0324 and approved on 29 March 2018).

Informed Consent Statement: Informed consent was obtained from all subjects involved in the study.

Data Availability Statement: The data for this study are held by the first author. For any access to the data, please contact the first author.

Acknowledgments: We would like to thank the reviewers for their constructive comments given to us.

Conflicts of Interest: The authors declare no conflict of interest.

\section{References}

1. Stubbs, W.; Cocklin, C. Teaching sustainability to business students: Shifting mindsets. Int. J. Sustain. High. Educ. 2008, 9, $206-221$. [CrossRef]

2. Kapferer, J.N.; Michaut-Denizeau, A. Is luxury compatible with sustainability? Luxury consumers' viewpoint. J. Brand Manag. 2014, 21, 1-22. [CrossRef]

3. Liu, L. Where in the world of sustainability education is US geography? J. Geogr. High. Educ. 2011, 35, 245-263. [CrossRef]

4. Braßler, M.; Sprenger, S. Fostering sustainability knowledge, attitudes and behaviours through a tutor-supported interdisciplinary course in education for sustainable development. Sustainability 2021, 13, 3494. [CrossRef]

5. Fjellborg, A.A.; Kramming, K. Sustainable development: Exploring gender differences in the Swedish national test in geography for grade 9. Int. Res. Geogr. Environ. Educ. 2021. [CrossRef]

6. National Core Curriculum for Basic Education (NFBE). National Core Curriculum for Basic Education Intended for Pupils in Compulsory Education; Finnish National Board of Education: Helsinki, Finland, 2004.

7. Uitto, A.; Saloranta, S. Subject teachers as educators for sustainability: A survey study. Educ. Sci. 2017, 7, 8. [CrossRef]

8. Goekler, J. Teaching for the future: Systems thinking and sustainability. Green Teach. 2003, 70, 8-14.

9. The United Nations Educational Scientific and Cultural Organisation (UNESCO). Education for Sustainable Development. Available online: https://en.unesco.org/themes/education-sustainable-development (accessed on 25 July 2021).

10. Liu, R.; Greene, R.; Li, X.; Wang, T.; Lu, M.; Xu, Y. Comparing geoinformation and geography students' spatial thinking skills with a human-geography pedagogical approach in a Chinese context. Sustainability 2019, 11, 5573. [CrossRef]

11. Yli-Panula, E.; Jeronen, E.; Lemmetty, P. Teaching and learning methods in geography promoting sustainability. Educ. Sci. 2020, 10, 5. [CrossRef]

12. Danaher, M.; Wu, J.; Hewson, M. Sustainability: A regional Australian experience of educating secondary geography teachers. Educ. Sci. 2021, 11, 126. [CrossRef]

13. Noble, T.; McGrath, H. Making it real and making it last! Sustainability of teacher implementation of a whole-school resilience programme. In Resilience in Education; Wosnitza, M., Peixoto, F., Beltman, S., Mansfield, C.F., Eds.; Springer: Cham, Switzerland, 2018; pp. 289-312.

14. Borg, C.; Gericke, N.; Höglund, H.-O.; Bergman, E. The barriers encountered by teachers implementing education for sustainable development: Discipline bound differences and teaching traditions. Res. Sci. Technol. Educ. 2012, 30, 185-207. [CrossRef] 
15. Chinese Ministry of Education (CMOE). Revision of the 2021 Edition of the New Geography Curriculum Standard for Compulsory Education; People's Education Press: Beijing, China, 2021. (In Chinese)

16. Massey, D. For Space; Sage: Thousand Oaks, CA, USA, 2005.

17. Cai, M. Also talk about how to develop junior middle school geography teaching under the background of new curriculum. New Curric. Res. 2015, 1, 34-35. (In Chinese)

18. Krathwohl, D.R. A revision of Bloom's Taxonomy: An overview. Theory Pract. 2002, 41, 212-218. [CrossRef]

19. Prensky, M. Homo sapiens digital: From digital immigrants and digital natives to digital wisdom. Innovate 2009, 5, 1552-3233.

20. Granados Sánchez, J. Teaching geography for a sustainable world: A case study of a secondary school in Spain. Rev. Int. Geogr. Educ. 2011, 1, 158-182.

21. Çifçi, T.; Koybaşi, F. Geographic consciousness in sustainable education: Students' views. J. Educ. Pract. 2017, 8, 49-55.

22. Zhang, L.; Zhang, S.; Chen, Z. On sustainable development education in geography teaching. J. Jilin Norm. Univ. (Humanit. Soc. Sci. Ed.) 2013, 6, 109-111. (In Chinese)

23. Hedden, M.K.; Worthy, R.; Akins, E.; Slinger-Friedman, V.; Paul, R.C. Teaching sustainability using an active learning constructivist approach: Discipline-specific case studies in higher education. Sustainability 2017, 9, 1320. [CrossRef]

24. Roberts, M. Teaching styles and strategies. In Geography in Education: Viewpoints on Teaching and Learning; Kent, A., Lambert, D., Naish, M., Slater, F., Eds.; Cambridge University Press: Cambridge, UK, 1996; pp. 231-259.

25. Raath, S.; Hay, A. Preservice geography students' exposure to systems thinking and cooperative learning in environmental education. J. Geogr. 2019, 118, 66-76. [CrossRef]

26. Yin, R.K. Case Study Research: Design and Methods; Sage: Thousand Oaks, CA, USA, 2013.

27. Sugimoto, A. The Back Burner: A Case Study of a Teacher's Dilemmas When Working with English Learners. Curriculum and Instruction Faculty Publications and Presentations. 2017. Available online: https://pdxscholar.library.pdx.edu/ci_fac/31 (accessed on 17 December 2021).

28. Rissanen, I.; Kuusisto, E.; Tuominen, M.; Tirri, K. In search of a growth mindset pedagogy: A case study of one teacher's classroom practices in a Finnish elementary school. Teach. Teach. Educ. 2019, 77, 204-213. [CrossRef]

29. Kooloos, C.; Oolbekkink-Marchand, H.; Kaenders, R.; Heckman, G. Orchestrating mathematical classroom discourse about various solution methods: Case study of a teacher's development. J. Math.-Didakt. 2020, 41, 357-389. [CrossRef]

30. Eisenhardt, K.M.; Graebner, M.E. Theory building from cases: Opportunities and challenges. Acad. Manag. J. 2007, 50, 25-32. [CrossRef]

31. Mariotto, F.L.; Zanni, P.P.; Salati, G.H.; De Moraes, M. What is the use of a single-case study in management research. RAE-Rev. Adm. Empresas (J. Bus. Manag.) 2014, 54, 358-369. [CrossRef]

32. Denzin, N.K.; Lincoln, Y.S.; Giardina, M.D. Disciplining qualitative research. Int. J. Qual. Stud. Educ. 2006, 19, 769-782. [CrossRef]

33. Haubrich, H.; Reinfried, S.; Schleicher, Y. Lucerne Declaration on Geographical Education for Sustainable Development. In Proceedings of the Symposium: Geographical Views on Education for Sustainable Development, Lucerne, Switzerland, 29-31 July 2007.

34. UNESCO. Education for Sustainable Development: Sourcebook; The United Nations Educational Scientific and Cultural Organisation: Paris, France, 2012.

35. De Sousa, L.M. Promoting Education for Sustainable Development: An Environmental Management Systems Framework for South African Primary Schools. Ph.D. Thesis, North-West University, Potchefstroom, South Africa, 2013.

36. Schuler, S.; Fanta, D.; Rosenkraenzer, F.; Riess, W. Systems thinking within the scope of education for sustainable development (ESD)_A heuristic competence model as a basis for (science) teacher education. J. Geogr. High. Educ. 2017, 42, 192-204. [CrossRef]

37. UNESCO. United Nations Contribution to the 2013 Agenda for Sustainable Development; The United Nations Educational Scientific and Cultural Organisation: Paris, France, 2015.

38. Jeronen, E.; Palmberg, I.; Yli-Panula, E. Teaching methods in biology education and sustainability education including outdoor education for promoting sustainability-A literature review. Educ. Sci. 2016, 7, 1. [CrossRef]

39. Morgan, J. Geography teaching for a sustainable society. In Reflective Practice in Geography Teaching; Kent, A., Ed.; Paul Chapman Publishing: London, UK, 2000; pp. 168-179.

40. Witoszek, N. Teaching sustainability in Norway, China and Ghana: Challenges to the UN programme. Environ. Educ. Res. 2018, 24, 831-844. [CrossRef]

41. Kowasch, M.; Lippe, D.F. Moral impasses in sustainability education? Empirical results from school geography in Austria and Germany. Environ. Educ. Res. 2019, 25, 1066-1082. [CrossRef]

42. Standish, A. Global Perspectives in the Geography Curriculum: Reviewing the Moral Case for Geography; Routledge: London, UK, 2009.

43. Lambert, D.; Morgan, J. Teaching Geography 11-18-A Conceptual Approach; Open University Press: New York, NY, USA, 2010.

44. Weston, A. Before environmental ethics. Environ. Ethics 1992, 14, 321-338. [CrossRef]

45. Habermas, J. Moral Consciousness and Communicative Action; Massachusetts Institute of Technology Press: Cambridge, MA, USA, 1990.

46. Wals, A.E.J. Between knowing what is right and knowing that is it wrong to tell others what is right: On relativism, uncertainty and democracy in environmental and sustainability education. Environ. Educ. Res. 2010, 16, 143-151. [CrossRef]

47. Martínez-Hernández, C.; Yubero, C. Explaining urban sustainability to teachers in training through a geographical analysis of tourism gentrification in Europe. Sustainability 2020, 12, 67. [CrossRef] 
48. Bruckner, H.; Kowasch, M. Moralising meat consumption: Bringing food and feeling into education for sustainable development. Policy Futures Educ. 2019, 17, 785-804. [CrossRef]

49. Kopnina, H. Metaphors of nature and development: Reflection on critical course of sustainable business. Environ. Educ. Res. 2016, 22, 571-589. [CrossRef]

50. Girardelli, D.; Patel, V.K.; Martins-Shannon, J. “Crossing the Rubicon": Understanding Chinese EFL students' volitional process underlying in-class participation with the theory of planned behavior. Educ. Res. Eval. 2017, 23, 119-137. [CrossRef]

51. Cheng, E.W.L. Students working online for group projects: A test of an extended theory of planned behaviour model. Educ. Psychol. 2017, 37, 1044-1056. [CrossRef]

52. Worden, R.L.; Savada, A.M.; Dolan, R.E. China: A Country Study. Washington: GPO for the Library of Congress. 1987. Available online: http:/ / countrystudies.us/china/ (accessed on 18 July 2021).

53. Whyte, M.K. Paradoxes of China's economic boom. Annu. Rev. Soc. 2009, 35, 371-392. [CrossRef]

54. Olsson, D.; Gericke, N. The effect of gender on students' sustainability consciousness: A nationwide Swedish study. J. Environ. Educ. 2017, 48, 357-370. [CrossRef]

55. Connell, R.W. Gender; Polity Press: Cambridge, UK, 2002.

56. Jones, M.G.; Howe, A.; Rua, M.J. Gender differences in students' experiences, interests and attitudes toward science and scientists. Sci. Educ. 2000, 84, 180-192. [CrossRef]

57. Sneddon, C.S. 'Sustainability' in ecological economics, ecology and livelihoods: A review. Prog. Human Geogr. 2000, 24, 521-549. [CrossRef]

58. Kowasch, M. Nickel Mining in Northern New Caledonia-A Path to Sustainable Development? J. Geochem. Explor. 2018, 194, 280-290. [CrossRef]

59. Liu, L. Sustainability: Living within one's own ecological means. Sustainability 2009, 1, 1412-1430. [CrossRef]

60. Eisenhardt, K.M. Building theories from case study research. Acad. Manag. Rev. 1989, 14, 532-550. [CrossRef]

61. Kessler, I.; Bach, S. Comparing cases. In Studying Organizations Using Critical Realism: A Practical Guide; Edwards, P.K., O’Mahoney, J., Vincent, S., Eds.; Oxford University Press: Oxford, UK, 2014; pp. 168-184. 